\title{
Adrenal inflammatory myofibroblastic tumour
}

\author{
Arun Chawla, ${ }^{1}$ Zeeshan Hameed, ${ }^{1}$ Dilip Mishra, ${ }^{1}$ Vidya Monappa ${ }^{2}$
}

${ }^{1}$ Department of Urology, Kasturba Medical College, Manipal, Manipal, India ${ }^{2}$ Department of Pathology, Kasturba Medical College, Manipal, Manipal, India

\section{Correspondence to} Dr Arun Chawla, urologyarun@yahoo.com
To cite: Chawla $A$, Hameed Z, Mishra D, et al. BMJ Case Rep Published online: [please include Day Month Year] doi:10.1136/ bcr-2013-010122

\section{SUMMARY}

A rare case of large adrenal mass which was nonfunctioning is presented. It is difficult to make preoperative diagnosis in these cases as the imaging findings are non-specific. Radical excision is mandatory as preoperative malignancy cannot be ruled out.

\section{BACKGROUND}

The differential diagnosis for large adrenal masses (more than $6 \mathrm{~cm}$ ) includes phaeochromocytoma, adrenal cortical tumour, Cushing's syndrome and adrenal metastasis. ${ }^{1}$ Inflammatory myofibroblastic tumour (IMT) is a rare tumour of unknown aetiology, occurring at various sites such as lungs, gastrointestinal tract, orbit and genitourinary tract. ${ }^{2}$ IMTs of the adrenal are rare and only two cases of adrenal IMT have been reported in literature. ${ }^{3} 4$ Imaging features of IMT are non-specific and hence, it is a dilemma to preoperatively differentiate these types of tumour from other conditions of adrenal gland. Histopathologically, it is composed of spindle cells (myofibroblasts) with inflammatory components like lymphocytes and plasma cells. We hereby report a case of large adrenal mass which was reported on histopathology as adrenal IMT.

\section{CASE PRESENTATION}

A 20-year-old boy presented with dull left flank ache. He was otherwise healthy without any endocrine symptoms. Family history was not suggestive of either multiple endocrine neoplasia syndrome, neurofibromatosis 1, Von Hippel-Lindau disease or familial pheochromocytoma/paraganglioma syndrome. Physical examination was essentially normal. His serum biochemical parameters for adrenal mass work-up were normal. The $24 \mathrm{~h}$ urinary catecholamines like metanephrine, normetanephrine and vanillylmandelic acid were within normal limits. Ultrasound abdomen revealed a $6 \mathrm{~cm} \times 6 \mathrm{~cm}$ hypoechoic mass occupying the left suprarenal region. Contrast enhanced CT (CECT) showed a well-defined heterogeneous hypodense lesion of size $6.8 \mathrm{~cm} \times 7 \mathrm{~cm} \times 5.5 \mathrm{~cm}$ with mild non-uniform arterial, porto-venous and delayedphase enhancement while no evidence of haemorrhage/calcification was seen, involving the left adrenal gland (figure 1A,B). The mass had replaced the left adrenal gland. The opposite gland was normal and there was no evidence of any other mass lesion in the abdomen.

The patient was planned for exploration, with preoperative preparation for any intraoperative haemodynamic changes. Under general anaesthesia, in the left flank position, the transperitoneal approach through the bed of the 11th rib, exploration revealed a $7 \mathrm{~cm} \times 6 \mathrm{~cm}$ encapsulated tumour of the left adrenal gland was found displacing the left renal vein. A complete surgical extirpation of the tumour was performed. There were no changes in the haemodynamic status during and after the resection of tumour. The postoperative course was uneventful. The excised specimen was sent for histopathological examination.

On gross examination, an encapsulated greyish brown mass measuring $6.5 \times 6 \times 5 \mathrm{~cm}$ with cut section showing pale yellow myxoid areas and peripherally compressed adrenal gland was seen. Histopathological study showed an encapsulated tumour composed of elongated spindle-shaped cells with vesicular elongate, indented nucleus and
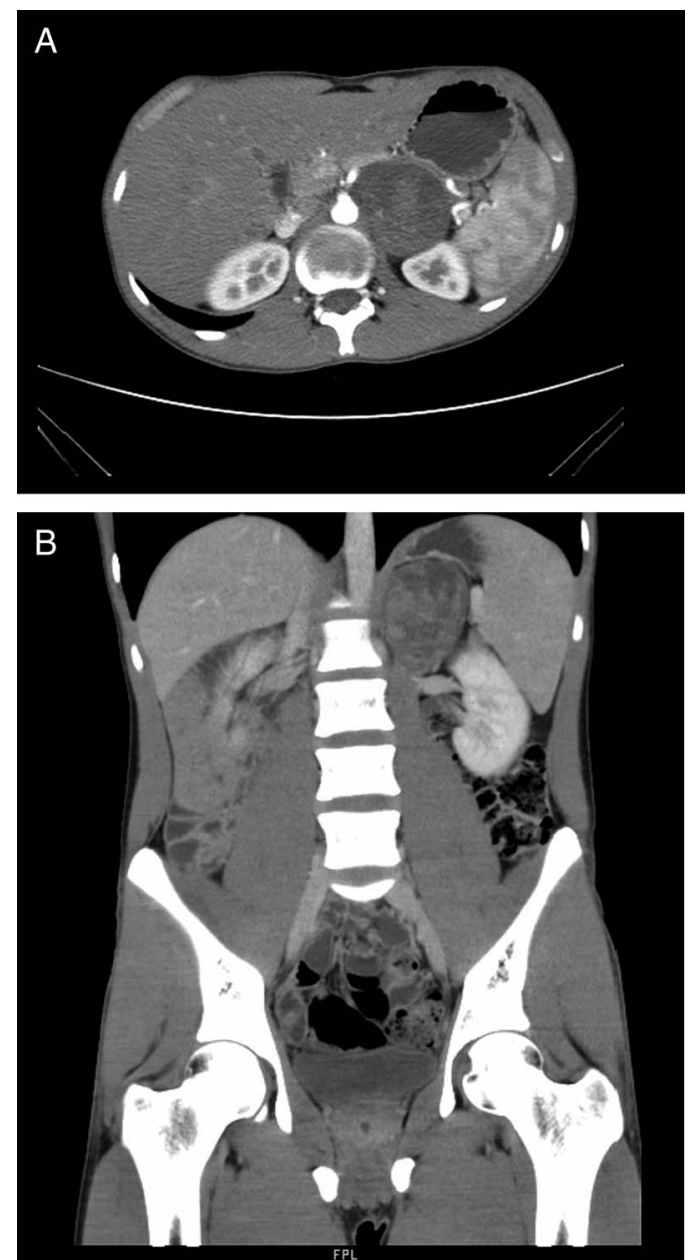

Figure 1 (A) Contrast enhanced CT (CECT) axial images showing a $6.8 \mathrm{~cm} \times 7 \mathrm{~cm} \times 5.5 \mathrm{~cm}$ well-defined heterogeneous hypodense lesion in the left adrenal gland. (B) CECT coronal images showing a $6.8 \mathrm{~cm} \times 7 \mathrm{~cm} \times 5.5 \mathrm{~cm}$ well-defined heterogeneous hypodense lesion in the left adrenal gland. 
abundant eosinophilic cytoplasm arranged in focal fascicles and in singles suspended in abundant myxoid stroma with interspread thin and thick walled blood vessels, scattered ganglion-like cells admixed with lymphocytes, plasma cells, eosinophils and few neutrophils (figure 2A,B). The features were suggestive of adrenal IMT.

\section{INVESTIGATIONS}

Ultrasound of the abdomen revealed a $6 \mathrm{~cm} \times 6 \mathrm{~cm}$ hypoechoic mass occupying the left suprarenal region. CECT showed a welldefined heterogeneous hypodense lesion of size $6.8 \mathrm{~cm} \times$ $7 \mathrm{~cm} \times 5.5 \mathrm{~cm}$ with mild non-uniform arterial, porto-venous and delayed-phase enhancement and no evidence of haemorrhage/ calcification was seen, involving the left adrenal gland (figure 1A,B). The mass had replaced the left adrenal gland. The opposite gland was normal and there was no evidence of any other mass lesion in the abdomen.

\section{DIFFERENTIAL DIAGNOSIS}

Phaeochromocytoma, adrenal cortical tumour, Cushing's syndrome, adrenal metastasis.

\section{TREATMENT}

The patient was planned for exploration, with preoperative preparation for any intraoperative haemodynamic changes. Under general anaesthesia, in the left flank position, the transperitoneal approach through the bed of the 11th rib, exploration revealed a $7 \mathrm{~cm} \times 6 \mathrm{~cm}$ encapsulated tumour of the left adrenal gland was found displacing the left renal vein. A complete surgical extirpation of the tumour was performed. There were no changes in the haemodynamic status during and after

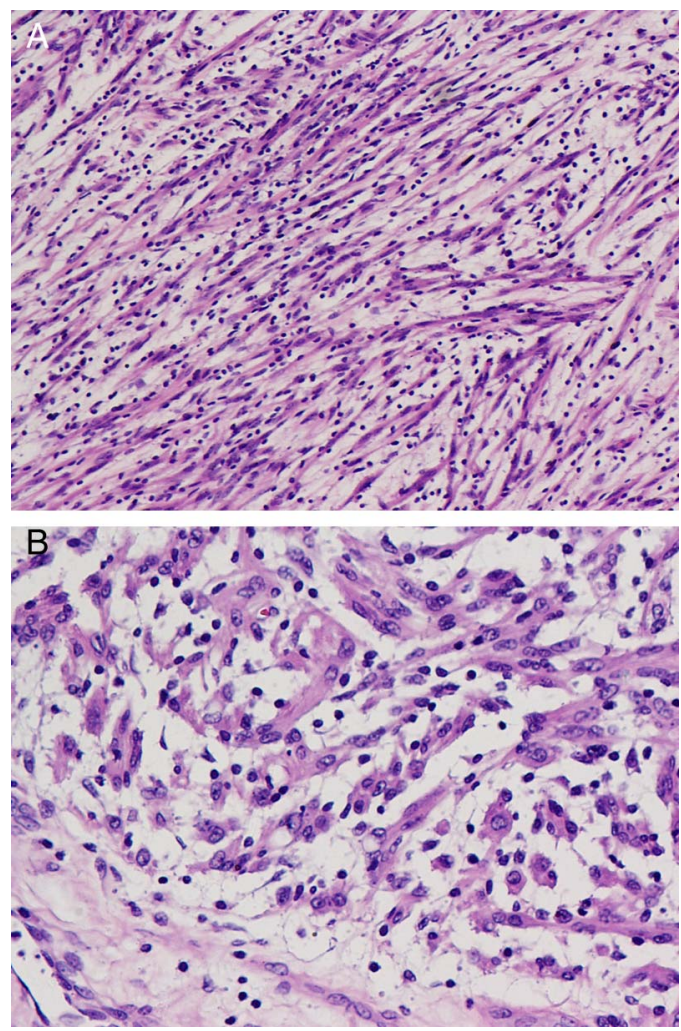

Figure 2 (A) Section shows elongated spindle-shaped cells suspended in abundant myxoid stroma with a sprinkling of lymphocytes. H\&E, $\times 200$ (B).Scattered ganglion-like rounded cells with enlarged nucleus seen. $H \& E, \times 400$. the resection of tumour. The postoperative course was uneventful. The excised specimen was sent for histopathological examination.

\section{OUTCOME AND FOLLOW-UP}

The patient is doing well after 3 months follow-up.

\section{DISCUSSION}

IMT is a relatively rare neoplasm. It was previously referred as plasma cell granuloma. IMT was first observed by Brunn in 1939. It was later termed inflammatory pseudotumour by Umiker and Iverson in 1954. It has long been debated regarding the origin of IMT, whether it was truly neoplastic or a postinflammatory process. IMT is usually seen in the lung, followed by the orbit. ${ }^{5}$ In the genitourinary tract, it most commonly occurs in the bladder. However, it rarely originates in the kidney, renal pelvis and ureter. Only two cases of adrenal IMT have been reported so far. Commonly seen in childhood or in adults, these tumours are considered benign. It has been described in almost any location, in both sexes and at all ages. They are usually asymptomatic; they rarely have symptoms like loss of weight, fever, decreased appetite and other vague symptoms. Similarly, our patient presented with dull flank ache without any associated symptoms.

On imaging, ultrasonography shows a variable pattern of echogenicity, and the lesion has been described as hypoechogenic or hyperechogenic with ill-defined or well-defined margins. ${ }^{6}$ CECT may show homogeneity or heterogeneity and hypodensity, isodensity or hyperdensity. ${ }^{7}$ IMT of the urinary tract is extremely difficult to distinguish from malignant tumours. In this patient, the CECT of abdomen disclosed findings of heterogeneous hypodense mass in left adrenal, which were non-specific.

Grossly, IMTs may be firm, fleshy or gelatinous, with a white or tan cut surface. Calcification, haemorrhage and necrosis are identified in a minority of cases. Tumours range from 1 to $20 \mathrm{~cm}$ in greatest dimension, with a mean size of $6 \mathrm{~cm}$. The histological differential diagnosis of IMT depends in part on the dominant pattern: myxoid/vascular, compact spindle cell or fibromatosis-like. It is characterised on the basis of electron microscopic and immunohistochemical findings. ${ }^{8}$ The WHO continues to classify IMT as a distinct borderline lesion with uncertainty as to whether it is reactive or neoplastic in nature. However, recent research suggests that IMT is probably a neoplasm with cytogenetic clonality, involvement of chromosomal region $2 \mathrm{p} 23$, occasional aggressive local behaviour and evidence of metastasis. ${ }^{6}$ Chromosomal translocations leading to activation of the anaplastic lymphoma kinase (ALK) tyrosine kinase and overexpression of the ALK protein can be detected in approximately $50 \%$ of IMTs, but are uncommon in older patients. Histological predictors of aggressive behaviour and metastatic potential include presence of ganglion-like cells, cellular atypia, aneuploidy and p53 overexpression. ${ }^{9}$ The present case showed scattered ganglion-like cells with enlarged nucleus (figure 2B).

The preoperative differentiation from other adrenal masses is very difficult. Though IMT will not make its place in the common differential diagnosis of adrenal masses, it should be kept in mind as one of the probability in background of indolent presentation and non-specific imaging findings. The definitive treatment is complete surgical resection of the tumour. Although recurrence of IMT arising from urinary bladder has been reported, recurrence of IMT in adrenal gland is yet not known. Still, it is advisable to keep these patients on regular follow-up. 


\section{Learning points}

- Adrenal inflammatory myofibroblastic tumour is a rare neoplasm of uncertain biological potential.

- Imaging findings are non-specific.

- Complete surgical resection remains the mainstay of the treatment.

\section{Competing interests None.}

Patient consent Obtained.

Provenance and peer review Not commissioned; externally peer reviewed.

\section{REFERENCES}

1 Belldegrun A, Hussain S, Seltzer SE, et al. The incidentally discovered adrenal mass: a therapeutic dilemma-BWH experience 1976-1983. Surg Gynecol Obstet 1986;163:203-8.
2 Narla LD, Newman B, Spottswood SS, et al. Inflammatory pseudotumor. Radiographics 2003;23:719-29.

3 Luo LK, Shen HF, Zhou SY, et al. Inflammatory myofibroblastic tumor of adrenal. Chin J Pathol 2006;35:252

4 Wang T-Y, Chou J-W, Shih Y-S. Inflammatory myofibroblastic tumor mimicking adrenal incidentaloma. Inter Med 2011;50:165-6.

5 Umiker WO, Iverson L. Postinflammatory tumors of the lung; report of four cases simulating xanthoma, fibroma, or plasma cell tumor. I Thorac Surg 1954;28:55-63.

6 Materne R, Van Beers BE, Gigot JF, et al. Inflammatory pseudotumor of the liver: MRI with mangafodipir trisodium. I Comput Assist Tomogr 1998;22:82-4.

7 Abehsera M, Vilgrain V, Belghiti J, et al. Inflammatory pseudotumor of the liver: radiologic-pathologic correlation. I Comput Assist Tomogr 1995;19:80-3.

8 Coffin CM, Watterson J, Priest JR, et al. Extrapulmonary inflammatory myofibroblastic tumor (inflammatory pseudotumor). A clinicopathologic and immunohistochemical study of 84 cases. Am J Surg Pathol 1995;19:859-72.

9 Attili SVS, Rama Chandra C, Hemant DK, et al. Retroperitoneal inflammatory myofibroblastic tumor. World J Surg Oncol 2005;3:66.

Copyright 2013 BMJ Publishing Group. All rights reserved. For permission to reuse any of this content visit http://group.bmj.com/group/rights-licensing/permissions.

BMJ Case Report Fellows may re-use this article for personal use and teaching without any further permission.

Become a Fellow of BMJ Case Reports today and you can:

- Submit as many cases as you like

- Enjoy fast sympathetic peer review and rapid publication of accepted articles

- Access all the published articles

- Re-use any of the published material for personal use and teaching without further permission

For information on Institutional Fellowships contact consortiasales@bmjgroup.com

Visit casereports.bmj.com for more articles like this and to become a Fellow 